Keywords: DWPF, SB7b, Tank

40, Waste Acceptance

Retention: Permanent

\title{
TANK 40 FINAL SB7b CHEMICAL CHARACTERIZATION RESULTS
}

\author{
C. J. Bannochie
}

November 2012

Savannah River National Laboratory Savannah River Nuclear Solutions Aiken, SC 29808

Prepared for the U.S. Department of Energy under contract number DE-AC09-08SR22470. 


\section{DISCLAIMER}

This work was prepared under an agreement with and funded by the U.S. Government. Neither the U.S. Government or its employees, nor any of its contractors, subcontractors or their employees, makes any express or implied:

1. warranty or assumes any legal liability for the accuracy, completeness, or for the use or results of such use of any information, product, or process disclosed; or

2. representation that such use or results of such use would not infringe privately owned rights; or

3. endorsement or recommendation of any specifically identified commercial product, process, or service.

Any views and opinions of authors expressed in this work do not necessarily state or reflect those of the United States Government, or its contractors, or subcontractors.

\section{Printed in the United States of America}

Prepared for U.S. Department of Energy 


\section{REVIEWS AND APPROVALS}

\section{AUTHORS:}

C. J. Bannochie, Process Technology Programs

Date

TECHNICAL REVIEW:

C. L. Crawford, Process Technology Programs

Date

APPROVAL:

C. C. Herman, Manager

Date

Process Technology Programs

Date

S. L. Marra, Manager

Environmental \& Chemical Process Technology Research Programs

J. W. Ray, Manager

Date

DWPF Regulatory Engineering 


\section{ACKNOWLEDGEMENTS}

The author would like to thank the Shielded Cells Operations (SCO) technicians for their attention and promptness in handling all of the samples generated by this activity. In addition, the assistance of Dr. Damon Click (Analytical Development) in preparing the aqua regia and alkali fusion digestions and John Pareizs (Process Technology Programs) in overseeing the weighted dilutions of slurry, are recognized. DWPF sludge batch data was supplied by Roger Mahannah (Savannah River Remediation, LLC). 


\section{EXECUTIVE SUMMARY}

A sample of Sludge Batch 7b (SB7b) was taken from Tank 40 in order to obtain radionuclide inventory analyses necessary for compliance with the Waste Acceptance Product Specifications (WAPS) ${ }^{\mathrm{i}}$. The SB7b WAPS sample was also analyzed for chemical composition including noble metals and fissile constituents, and these results are reported here. These analyses along with the WAPS radionuclide analyses will help define the composition of the sludge in Tank 40 that is currently being fed to the Defense Waste Processing Facility (DWPF) as SB7b.

At the Savannah River National Laboratory (SRNL) the 3-L Tank 40 SB7b sample was transferred from the shipping container into a 4-L high density polyethylene bottle and solids were allowed to settle over the weekend. Supernate was then siphoned off and circulated through the shipping container to complete the transfer of the sample. Following thorough mixing of the 3-L sample, a $558 \mathrm{~g}$ sub-sample was removed. This sub-sample was then utilized for all subsequent analytical samples.

Eight separate aliquots of the slurry were digested, four with $\mathrm{HNO}_{3} / \mathrm{HCl}$ (aqua regiai ${ }^{\mathrm{ii}}$ ) in sealed Teflon ${ }^{\circledR}$ vessels and four with $\mathrm{NaOH} / \mathrm{Na}_{2} \mathrm{O}_{2}$ (alkali or peroxide fusion ${ }^{\text {iii }}$ ) using $\mathrm{Zr}$ crucibles. Two Analytical Reference Glass - $1^{\text {iv }}$ (ARG-1) standards were digested along with a blank for each preparation. Each aqua regia digestion and blank was diluted to $1: 100 \mathrm{~mL}$ with deionized water and submitted to Analytical Development (AD) for inductively coupled plasma - atomic emission spectroscopy (ICP-AES) analysis, inductively coupled plasma - mass spectrometry (ICP-MS) analysis, atomic absorption spectroscopy (AA) for As and Se, and cold vapor atomic absorption spectroscopy (CV-AA) for Hg. Equivalent dilutions of the alkali fusion digestions and blank were submitted to AD for ICP-AES analysis.

Tank 40 SB7b supernate was collected from a mixed slurry sample in the SRNL Shielded Cells and submitted to AD for ICP-AES, ion chromatography (IC), total base/free $\mathrm{OH}^{-}$/other base, total inorganic carbon/total organic carbon (TIC/TOC) analyses, and Cs-137 gamma scan ${ }^{\mathrm{v}}$. Weighted dilutions of slurry were submitted for IC, TIC/TOC, and total base/free $\mathrm{OH}^{\circ} /$ other base analyses.

Activities for U-233, U-235, and Pu-239 were determined from the ICP-MS data for the aqua regia digestions of the Tank 40 WAPS slurry using the specific activity of each isotope. The Pu-241 value was determined from a Pu-238/-241 method developed by SRNL AD and previously described. ${ }^{\mathrm{vi}}$

The following conclusions were drawn from the analytical results reported here:

\footnotetext{
${ }^{\mathrm{i}}$ Office of Environmental Restoration and Waste Management, Waste Acceptance Product Specifications for Vitrified High-Level Waste Forms, US DOE Document DOE/EM-0093, Rev. 2, (12/96).

${ }^{\text {ii }}$ Coleman, C. J. Aqua Regia Dissolution of Sludge for Elemental Analysis, Manual L16.1, Procedure ADS-2226, Rev. 9, Savannah River Site, Aiken, SC 29808 (2009).

iii Coleman, C. J. Alkali Fusion Dissolutions of Sludge and Glass for Elemental and Anion Analysis, Manual L16.1, ADS-2502, Rev. 6, Savannah River Site, Aiken, SC 29808 (2008).

iv Smith, G. L. Characterization of Analytical Reference Glass - 1 (ARG-1), PNL-8992, Pacific Northwest (National) Laboratory, Richland, WA (1993).

v Bannochie, C. J., DiPrete, D. P. Determination of Reportable Radionuclides for DWPF Sludge Batch 6 (Macrobatch 7), SRNLSTI-2011-000189, Savannah River Site, Aiken, SC 29808 (2011).

${ }^{v i}$ Bannochie, C. J., DiPrete, D. P. Determination of Reportable Radionuclides for DWPF Sludge Batch 6 (Macrobatch 7), SRNL-STI-2011-000189, Savannah River Site, Aiken, SC 29808 (2011).
} 
- The ratios of the major elements for the SB7b WAPS sample are different from those measured for the SB7a WAPS sample. There is less $\mathrm{Al}$ and $\mathrm{Mn}$ relative to Fe than the previous sludge batch.

- The elemental composition of this sample and the analyses conducted here are reasonable and consistent with DWPF batch data measurements in light of DWPF pre-sample concentration and SRAT product heel contributions to the DWPF SRAT receipt analyses. The element ratios for $\mathrm{Al} / \mathrm{Fe}, \mathrm{Ca} / \mathrm{Fe}, \mathrm{Mn} / \mathrm{Fe}$, and U/Fe agree within $10 \%$ between this work and the DWPF Sludge Receipt and Adjustment Tank (SRAT) receipt analyses.

- Sulfur in the SB7b WAPS sample is $82 \%$ soluble, slightly less than results reported for SB3, SB4, and SB6 samples but unlike the 50\% insoluble sulfur observed in the SB5 WAPS sample. In addition, $23 \%$ of the soluble sulfur is not present as sulfate in SB7b.

- The average activities of the fissile isotopes of interest in the SB7b WAPS sample are (in $\mu \mathrm{Ci} / \mathrm{g}$ of total dried solids): 4.22E-02 U-233, 6.12E-04 U-235, 1.08E+01 Pu-239, and 5.09E+01 Pu241. The full radionuclide composition will be reported in a future document.

- The fission product noble metal and Ag concentrations appear to have largely peaked in previous DWPF sludge batches, with the exception of Ru, which still shows a slight increase in SB7b. 


\section{TABLE OF CONTENTS}

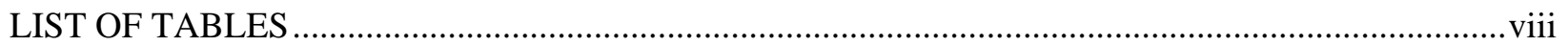

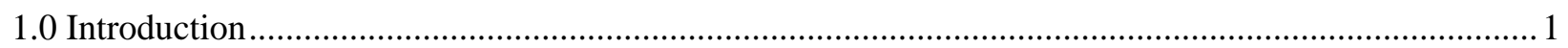

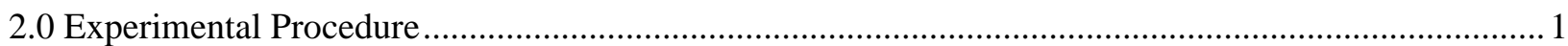

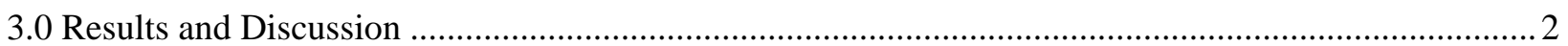

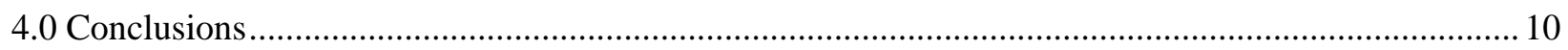

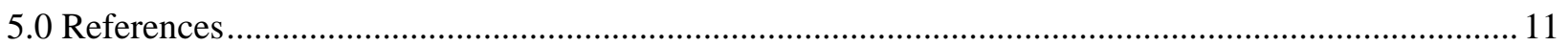

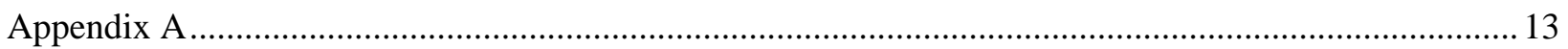


SRNL-STI-2012-00097

Revision 1

\section{LIST OF TABLES}

Table 3-1. Weight Percent Solids and Density for Tank 40 SB7b WAPS Samples and DWPF SRAT Receipt Batch 614 [Number of Samples Included in Average]

Table 3-2. Supernate Analyses for Tank 40 SB7b WAPS Samples and DWPF SRAT Receipt Batch 614 [Number of Samples Included in Average].

Table 3-3. Carbon Analysis for Tank 40 SB7b WAPS Samples and DWPF SRAT Receipt Batch 614 [Number of Samples Included in Average] (mg C/kg slurry) ............................................... 4

Table 3-4. Base Analysis for Tank 40 SB7b WAPS Samples and DWPF SRAT Receipt Batch 614 [Number of Samples Included in Average] (mol/kg slurry).

Table 3-5. Elemental Concentrations* in Tank 40 SB7b WAPS Samples in Wt. \% of Total Dried Solids $\left(\% \mathrm{RSD}^{* *}\right)$ [Number of Samples Included in Average]

Table 3-6. Comparison of Elemental Ratios for Major Insoluble Elements in the Tank 40 SB4, SB5, SB6, SB7a and SB7b Samples with DWPF Batch 614 SRAT Receipt Data.

Table 3-7. Replicate Concentrations of Iron for the Tank 40 SB7b WAPS Sample in Wt.\% of Total Dried Solids

Table 3-8. Replicate Activities of Fissile Radionuclides for the Tank 40 SB7b WAPS Sample in $\mu$ Ci/g of Total Dried Solids

Table 3-9. Replicate Weight Percent Solids and Densities for Tank 40 SB7b WAPS Sample 8

Table 3-10.Cesium-137 Concentration in the Tank 40 SB7b WAPS Sample Supernate in dpm/mL $\left(\% \mathrm{RSD}^{* *}\right.$ ) [Number of Samples Included in Average]

Table 3-11. Noble Metal Fission Product and Silver Concentrations in Tank 40 SB4, SB5, SB6, SB7a, and SB7b WAPS Samples in Wt. \% of Total Solids (\%RSD)

Table 3-12. Fission Yield Ratios and Measured Noble Metal Ratios in SB4, SB5, SB6, SB7a, and SB7b WAPS Samples

Table A-1. ICP-AES Results for Elements Reported Based on ICP-MS Data in Table 3-5 for Tank 40 SB7b WAPS Samples in Wt.\% of Total Dried Solids (\%RSD**) [Number of Samples Included in Average].

\section{LIST OF FIGURES}

Figure 3-1 Noble Metal Fission Product and Silver Concentrations (Wt. \% of Total Solids) in Tank 40 WAPS Samples for SB4 through SB7b. 


\section{LIST OF ABBREVIATIONS}

\begin{tabular}{|c|c|}
\hline $\mathrm{AD}$ & Analytical Development \\
\hline ARG -1 & Analytical Reference Glass - 1 \\
\hline ASP & Analytical Study Plan \\
\hline CV-AA & Cold Vapor - Atomic Absorption Spectroscopy \\
\hline DWPF & Defense Waste Processing Facility \\
\hline HLW & High Level Waste \\
\hline IC & Ion Chromatography \\
\hline ICP-AES & Inductively Coupled Plasma - Atomic Emission Spectroscopy \\
\hline ICP-MS & Inductively Coupled Plasma - Mass Spectrometry \\
\hline $\mathrm{L}$ & Liter \\
\hline$\mu \mathrm{Ci}$ & Microcuries \\
\hline M & Molar \\
\hline NA & Not Available (e.g. Not Measured) \\
\hline RSD & Relative Standard Deviation \\
\hline SB3 & Sludge Batch 3 \\
\hline SB4 & Sludge Batch 4 \\
\hline SB5 & Sludge Batch 5 \\
\hline SB6 & Sludge Batch 6 \\
\hline SB7a & Sludge Batch 7a \\
\hline SB7b & Sludge Batch 7b \\
\hline SRAT & Sludge Receipt and Adjustment Tank \\
\hline SRNL & Savannah River National Laboratory \\
\hline Std. Dev. & Standard Deviation \\
\hline TC & Total Carbon \\
\hline TIC & Total Inorganic Carbon \\
\hline TOC & Total Organic Carbon \\
\hline TS & Total Dried Solids \\
\hline TTQAP & Task Technical and Quality Assurance Plan \\
\hline TTR & Technical Task Request \\
\hline WAPS & Waste Acceptance Product Specifications \\
\hline Wt.\% & Weight Percent \\
\hline
\end{tabular}




\subsection{Introduction}

A sample of Sludge Batch 7b (SB7b) was pulled from Tank 40 in order to obtain radionuclide inventory analyses necessary for compliance with the Waste Acceptance Product Specifications (WAPS) ${ }^{1}$. The SB7b WAPS sample was also analyzed for chemical composition, including noble metals, and fissile constituents, and these results are reported here. These analyses along with the WAPS radionuclide analyses will help define the composition of the sludge in Tank 40 that is currently being fed to the Defense Waste Processing Facility (DWPF) as SB7b.

Savannah River National Laboratory (SRNL) analyses on SB7b were requested by DWPF via Technical Task Request (TTR) HLW-DWPF-TTR-2011-0004². The sample preparation work is governed by a Task Technical and Quality Assurance Plan (TTQAP) ${ }^{3}$, and analyses were controlled by an Analytical Study Plan ${ }^{4}$.

One 3-L sample of Tank 40 was pulled and delivered on January 19, 2012 following slurry operations. Four slurry pumps were operated for a minimum of eight out of the 10 hours preceding sample collection, and the sample was collected not more than one hour after discontinuing slurry operations. The general protocol is for all four slurry pumps to run for eight hours before a DWPF transfer and to be kept running during the transfer, but due to the need to pull a sample, the pumps had to be shut down. The tank level was 206.2 inches after the pumps were secured and when the sample was pulled.

\subsection{Experimental Procedure}

At SRNL, the 3-L Tank 40 SB7b sample was transferred from the shipping container into a 4-L high density polyethylene bottle and solids were allowed to settle over the weekend. Supernate was then siphoned off and circulated through the shipping container to complete the transfer of the sample. Following thorough mixing of the 3-L sample, a $558 \mathrm{~g}$ sub-sample was removed. This sub-sample was then utilized for all subsequent analytical samples.

Eight separate aliquots of the slurry were digested, four with $\mathrm{HNO}_{3} / \mathrm{HCl}$ (aqua regia ${ }^{5}$ ) in sealed Teflon ${ }^{\circledR}$ vessels and four with $\mathrm{NaOH} / \mathrm{Na}_{2} \mathrm{O}_{2}$ (alkali or peroxide fusion ${ }^{6}$ ) using $\mathrm{Zr}$ crucibles. Due to the use of $\mathrm{Zr}$ crucibles and $\mathrm{Na}$ in the peroxide fusions, $\mathrm{Na}$ and $\mathrm{Zr}$ cannot be determined from this preparation. Additionally, other alkali metals, such as $\mathrm{Li}$ and $\mathrm{K}$ that may be contaminants in the $\mathrm{NaOH} / \mathrm{Na}_{2} \mathrm{O}_{2}$ are not determined from this preparation. Two Analytical Reference Glass - $1^{7}$ (ARG-1) standards were digested along with a blank for each preparation. The ARG-1 glass allows for an assessment of the completeness of each digestion. A multielement metal ion standard was submitted with each digestion, and the elemental checks were generally within $\pm 5 \%$ of the expected value. Each aqua regia digestion and blank was diluted to 1:100 mL with deionized water and submitted to Analytical Development (AD) for inductively coupled plasma - atomic emission spectroscopy (ICP-AES) analysis, inductively coupled plasma - mass spectrometry (ICP-MS) analysis of masses 82-208 and 230-244, atomic absorption spectroscopy (AA) for As and Se, and cold vapor atomic absorption spectroscopy (CV-AA) analysis for Hg. Equivalent dilutions of the alkali fusion digestions and blank were submitted to AD for ICP-AES analysis.

Tank 40 SB7b supernate was collected from a mixed slurry sample in the SRNL Shielded Cells and submitted to AD for ICP-AES, ion chromatography (IC), total inorganic carbon/total organic carbon (TIC/TOC), total base/free $\mathrm{OH}^{\circ} /$ other base analyses, and Cs-137 gamma scan ${ }^{8}$. Weighted dilutions of slurry were submitted for IC, TIC/TOC, and total base/free $\mathrm{OH}^{-}$/other base analyses. 
Activities for U-233, U-235, and Pu-239 were determined from the ICP-MS data for the aqua regia digestions of the Tank 40 WAPS slurry using the specific activity of each isotope. The Pu-241 value was determined from a Pu-238/-241 method developed by SRNL AD and previously described. ${ }^{8}$

\subsection{Results and Discussion}

Table 3-1 presents the measured SB7b density and weight percent solids data ${ }^{9,10}$ collected for the SB7b WAPS sample taken in January 2012. Table 3-1 also contains data from the DWPF Sludge Receipt and Adjustment Tank (SRAT) receipt sample data for Batch \#614 as a comparison. Batch \#614 was selected because it was the fifth DWPF batch received from Tank 40 following the start of SB7b processing and both the SRAT heel and receipt material should represent SB7b material. The wt. \% total solids for the Tank 40 - WAPS sample is lower than that seen for Batch \#614, and it would be expected to be lower than the total solids observed for the DWPF SRAT receipt batch due to the impacts of the SRAT heel and DWPF pre-sample concentration of incoming Tank 40 transfers. The SRAT heel contributes approximately $13-19 \%$ of the volume of slurry in the SRAT vessel and can have total solids in the range of $20 \mathrm{wt}$. \%. Calcine factors were also calculated by taking the ratio of the weight percent calcined solids and the weight percent total solids. The Tank 40 - WAPS Sample has a value of 0.80 grams of calcined solids per gram of dried solids.

Table 3-1. Weight Percent Solids and Density for Tank 40 SB7b WAPS Samples and DWPF SRAT Receipt Batch 614 [Number of Samples Included in Average]

\begin{tabular}{|c|c|c|}
\hline Property & $\begin{array}{c}\text { Tank } 40 \text { - WAPS } \\
(\% \text { RSD*) }\end{array}$ & $\begin{array}{c}\text { DWPF SRAT } \\
\text { Receipt for } \\
\text { Batch } 614^{\mathrm{a}}\end{array}$ \\
\hline Slurry Density & $1.12(0.6)[4]$ & $1.11^{\mathrm{d}}$ \\
\hline Supernate Density & $1.05(0.4)[5]$ & NA \\
\hline $\begin{array}{l}\text { Wt. \% Total } \\
\text { Solids }\end{array}$ & $15.64(0.2)[4]$ & $18.05^{\mathrm{d}}$ \\
\hline $\begin{array}{l}\text { Wt. \% Calcined } \\
\text { Solids }\end{array}$ & $12.50(2.8)[4]$ & NA \\
\hline $\begin{array}{l}\text { Wt. \% Dissolved } \\
\text { Solids }^{\mathrm{b}}\end{array}$ & $5.48(0.2)[4]$ & NA \\
\hline $\begin{array}{l}\text { Wt. \% Insoluble } \\
\text { Solids }\end{array}$ & 10.75 & NA \\
\hline $\begin{array}{l}\text { Wt. \% Soluble } \\
\text { Solids }^{c}\end{array}$ & 4.89 & NA \\
\hline \multicolumn{3}{|c|}{$\begin{array}{l}\text { NA } \equiv \text { not measured } \\
\text { * Parenthetical \%RSD values are relative to the true calculated averages of the quantities in the table, } \\
\text { while the average values reported have been rounded off to a reasonable number of significant figures. } \\
\text { a Measured in DWPF } \\
\text { b Also known as Uncorrected Soluble Solids } \\
\text { CAlso known as Corrected Soluble Solids } \\
\text { d DWPF calculations give } 16.05 \text { wt.\% total solids and a density of } 1.09 \text { when the effect of the SRAT heel } \\
\text { and pre-concentration is removed. }\end{array}$} \\
\hline
\end{tabular}


Table 3-2 provides the anion results for the Tank 40 WAPS sample and the available DWPF SRAT receipt data for Batch \#614. In order to compare the data from the two labs it was necessary to put the SRNL data on a slurry basis. SRNL data in Columns 2 and 3 of the table are presented on a supernate basis, i.e. moles/L of supernate, but were the result of weighted dilutions of supernate and weighted dilutions of slurry, respectively. Columns 4 and 5 in the table are presented on a slurry basis, i.e. $\mathrm{mg} / \mathrm{kg}$ slurry, but were the result of weighted dilutions of supernate and weighted dilutions of slurry, respectively. As a result, Columns 2 and 4 are from the same set of weighted dilutions, and Columns 3 and 5 are from a separate set of weighted dilutions.

The supernate sulfur result given for SRNL is calculated from total sulfur detected in the supernate by ICP-AES and is about $30 \%$ higher, on a molar basis, than sulfate sulfur determined by IC. This difference between total soluble sulfur and sulfate soluble sulfur was observed throughout SB6 washing $^{11}$ and it appears to be true again for SB7b. The Al, Ca, Cr, K, Mo, Na, and S values also shown in this table were calculated from the ICP-AES data for the supernate and placed on a slurry basis using the insoluble solids content from Table 3-1. Other supernate elements measured were below the ICPAES detection limits.

Table 3-2. Supernate Analyses for Tank 40 SB7b WAPS Samples and DWPF SRAT Receipt Batch 614 [Number of Samples Included in Average]

\begin{tabular}{|c|c|c|c|c|c|c|}
\hline Analyte & $\begin{array}{c}\text { SB7b WAPS } \\
\text { (\%RSD*) } \\
\text { Mol/L super. } \\
\text { Wt'd Dil. Slurry }\end{array}$ & $\begin{array}{c}\text { SB7b WAPS } \\
\text { (\%RSD*) } \\
\text { Mol/L super. } \\
\text { Wt’d Dil. Super. }\end{array}$ & $\begin{array}{c}\text { SB7b WAPS } \\
\text { (\%RSD*) } \\
\text { mg/kg slurry } \\
\text { Wt'd Dil. Slurry }\end{array}$ & $\begin{array}{c}\text { SB7b WAPS } \\
\text { (\%RSD*) } \\
\text { mg/kg slurry } \\
\text { Wt'd Dil. Super. }\end{array}$ & Method & $\begin{array}{c}\text { SRAT } \\
\text { Receipt for } \\
\text { Batch } 614 \\
\text { mg/kg slurry }\end{array}$ \\
\hline $\mathrm{NO}_{3}^{-}$ & $0.0953(0.6)[4]$ & $0.0975(0.8)[4]$ & $5030(0.6)[4]$ & $5150(0.8)[4]$ & IC & 8490 \\
\hline $\mathrm{NO}_{2}^{-}$ & $0.232(1.1)[4]$ & $0.233(0.7)[4]$ & $9090(1.1)[4]$ & $9140(0.7)[4]$ & IC & 8790 \\
\hline $\mathrm{SO}_{4}{ }^{2-}$ & $0.0181(1.0)[4]$ & 0.0179 (1.4) [4] & $1480(1.0)[4]$ & 1460 (1.4) [4] & IC & 1880 \\
\hline $\mathrm{PO}_{4}{ }^{3-}$ & $<0.0052$ & $<0.0033$ & $<418$ & $<268$ & IC & NA \\
\hline $\mathrm{I}^{-* *}$ & NA & 1.19E-08 (8.5) [4] & NA & $1.29(8.5)[4]$ & ICP-MS & NA \\
\hline $\mathrm{Br}^{-}$ & $<0.0061$ & $<0.0039$ & $<418$ & $<268$ & IC & NA \\
\hline $\mathrm{Cl}^{-}$ & $<0.014$ & $<0.0089$ & $<418$ & $<268$ & IC & NA \\
\hline $\mathrm{CHO}_{2}^{-}$ & $<0.011$ & $<0.0070$ & $<418$ & $<268$ & IC & 6250 \\
\hline $\mathrm{C}_{2} \mathrm{O}_{4}^{2-}$ & $0.0399(1.0)[4]$ & $0.0394(0.6)[4]$ & $2990(1.0)[4]$ & $2950(0.6)[4]$ & IC & 3670 \\
\hline $\mathrm{F}^{-}$ & $<0.026$ & $<0.017$ & $<418$ & $<268$ & IC & NA \\
\hline $\mathrm{Al}$ & NA & $0.0357(0.1)[4]$ & NA & $820(0.1)[4]$ & ICP-AES & NA \\
\hline $\mathrm{Ca}$ & NA & 0.000116 (3.6) [4] & NA & 3.97 (3.6) [4] & ICP-AES & NA \\
\hline $\mathrm{Cr}$ & NA & $0.000442(0.6)[4]$ & NA & $19.6(0.6)[4]$ & ICP-AES & NA \\
\hline $\mathrm{Fe}$ & NA & $0.0000108(12)[2]$ & NA & $0.513(12)[2]$ & ICP-AES & NA \\
\hline $\mathrm{K}$ & NA & 0.00189 (17) [3] & NA & 62.8 (17) [3] & ICP-AES & NA \\
\hline Mo & NA & 0.0000496 (9.7) [2] & NA & 4.05 (9.7) [2] & ICP-AES & NA \\
\hline $\mathrm{Na}$ & NA & $0.979(0.5)[4]$ & NA & $19200(0.5)[4]$ & ICP-AES & NA \\
\hline S & NA & 0.0231 (3.1) [4] & NA & $632(3.1)[4]$ & ICP-AES & NA \\
\hline
\end{tabular}


A comparison of anion data, shown in Table 3-2, for this sample and the DWPF SRAT Receipt Batch \#614 is difficult due to a number of factors. The DWPF SRAT receipt nitrite ion concentration would be expected to be reduced relative to the incoming sludge since the heel in the SRAT is reduced in nitrite ion. Similarly, the SRAT formate and nitrate ion concentrations would be expected to be elevated relative to the sludge since the heel in the SRAT is greatly increased in these anions. The nitrite to nitrate ratio observed is considerably different, but is likely due to the large residual heel in the SRAT vessel and the concentration of DWPF SRAT receipt material prior to sampling. This pre-concentration of the SRAT receipt material, prior to sampling and analysis, makes a comparison of anion levels very difficult for this sludge batch. Some past sludge batches have been higher in incoming insoluble solids and did not require this pre-concentration boil prior to routine SRAT processing.

The conversion of the total supernate sulfur value, as shown in Table 3-2, from molar to wt.\% of total solids, yields 0.403 wt.\% ( $\pm 3.1 \%$ RSD) S for the Tank 40 - SB7b WAPS sample. Comparing this value with the total slurry sulfur value in Table 3-5 (0.490 wt.\% $\pm 1.7 \%$ RSD) indicates that $~ 82 \%$ of the sulfur in the WAPS sample is soluble. For SB3 ${ }^{12}, \mathrm{SB} 4^{14}$ and $\mathrm{SB}^{15}, 95 \%, 93 \%$, and $91 \%$ of the sulfur was soluble, respectively, while the SB5 WAPS sample had only $50 \%$ of the sulfur present in the supernate phase. Since the total sulfur content does not exceed any glass limits, there should not be any negative consequences to the speciation of the sulfur in SB7b. When the SB7b WAPS supernate sulfur value by ICP-AES (Table 3-2 ) is put on a slurry sulfate basis, the result is $1890 \mathrm{mg}$ sulfate/kg slurry. This compares well with the DWPF sulfate analysis for Batch \#614 of $1880 \mathrm{mg}$ sulfate/kg slurry.

Table 3-3 provides the TIC and TOC measured for the SB7b WAPS sample along with the total carbon (TC) value which is reported as the sum of the TIC and TOC values. The first column of values resulted from a weighted dilution of the slurry into water, while the second column of values resulted from a weighted dilution of supernate into water. Note however that both sets of results are reported on a slurry basis. The slurry value of TIC is needed for current SRAT processing acid calculations while the supernate TIC value is needed for developmental work on a revised acid calculation, hence both dilution methods were undertaken. The data does support earlier observations that there is an undissolved slurry TIC component that is not measured if only the supernate TIC is measured. It does not demonstrate, however, that the current slurry TIC measurement actually succeeds in dissolving the entire insoluble TIC; hence the $490 \mathrm{mg} / \mathrm{kg}$ insoluble TIC observed is a lower bound on the actual insoluble TIC value. The slurry TIC value measured for SRAT Batch \#614 is 43\% lower than the slurry value determined in SRNL, but no TOC or TC values are available for comparison.

Table 3-3. Carbon Analysis for Tank 40 SB7b WAPS Samples and DWPF SRAT Receipt Batch 614 [Number of Samples Included in Average] (mg C/kg slurry)

\begin{tabular}{lccc}
\hline Analyte & $\begin{array}{c}\text { Slurry Wt'd Dilution } \\
\text { Tank 40 - WAPS } \\
\text { (\%RSD*) }\end{array}$ & $\begin{array}{c}\text { Supernate Wt'd Dilution } \\
\text { Tank 40 - WAPS } \\
\text { (\%RSD*) }\end{array}$ & $\begin{array}{c}\text { SRAT } \\
\text { Receipt for } \\
\text { Batch 614 }^{\text {a }}\end{array}$ \\
\hline $\begin{array}{c}\text { Total Inorganic } \\
\text { Carbon }\end{array}$ & $1610(5.8)[4]$ & $1120(3.1)[4]$ & 918 \\
$\begin{array}{c}\text { Total Organic } \\
\text { Carbon } \\
\text { Total Carbon }\end{array}$ & $1210(6.1)[4]$ & $1050(1.3)[4]$ & NA \\
\hline $\begin{array}{l}\text { NA } \equiv \text { not measured } \\
\text { * Parenthetical \%RSD values are relative to the true calculated averages of the quantities in the table, while the average values } \\
\text { reported have been rounded off to a reasonable number of significant figures. }\end{array}$ & NA \\
a Measured in DWPF &
\end{tabular}


Table 3-4 provides the base measurements made on the SB7b WAPS sample. Total base represents the value determined from an inflection endpoint titration to $\mathrm{pH}$ 7. Free $\mathrm{OH}^{-}$represents the value determined after precipitation of carbonate with $\mathrm{BaCl}_{2}$ and titration to the first inflection endpoint between $\mathrm{pH} 11$ and 8. Further titration of this treated sample to $\mathrm{pH} 7$ yields the value for other base.

Table 3-4. Base Analysis for Tank 40 SB7b WAPS Samples and DWPF SRAT Receipt Batch 614 [Number of Samples Included in Average] (mol/kg slurry)

\begin{tabular}{|c|c|c|c|}
\hline Analyte & $\begin{array}{c}\text { Slurry Wt'd Dilution } \\
\text { Tank } 40 \text { - WAPS } \\
\text { (\%RSD) }\end{array}$ & $\begin{array}{c}\text { Supernate Wt'd Dilution } \\
\text { Tank 40 - WAPS } \\
\text { (\%RSD) }\end{array}$ & $\begin{array}{c}\text { SRAT } \\
\text { Receipt for } \\
\text { Batch } 614^{\mathrm{a}}\end{array}$ \\
\hline Total Base & $0.288(3.4)[4]$ & $0.283(3.6)[4]$ & 0.430 \\
\hline Free $\mathrm{OH}^{-}$ & $0.184(4.9)[4]$ & 0.142 (12) [4] & NA \\
\hline Other Base & 0.112 (1.8) [4] & $<0.134$ & NA \\
\hline
\end{tabular}

The difference between the total base value when free $\mathrm{OH}^{-}$and 'other base' are removed should correspond to the carbonate base equivalents determined via titration. This value, 0.14 moles base $/ \mathrm{kg}$ slurry, should correspond to the TIC base equivalents for carbonate determined from the data in Table 3-3. The value of TIC for the slurry weighted dilution gives 0.27 moles base/kg slurry, while the TIC value from the supernate weighted dilution gives 0.19 moles base/kg slurry. The supernate determined value would be expected to be lower than the slurry value if there are undissolved carbonates in the solids that are dissolved when the slurry is diluted into water. The carbonate base value (determined from the data in Table 3-4) that was derived from a weighted dilution of supernate is low even if the 'other base' value is assumed to be zero. On the other hand, the carbonate base value derived from a weighted dilution of slurry is effectively zero, which implies that one or both of the reported free $\mathrm{OH}$ - or the 'other base' values is too high, i.e. a sum of the two exceeds the total base value without consideration of the contribution from carbonate species.

The elemental concentrations determined from ICP-AES, ICP-MS, AA, and CV-AA analyses are presented in Table 3-5. For the Tank 40 - WAPS sample, results from both digestions have been combined where appropriate. When both detection limits and actual values are measured for replicates, only the actual value(s) are included in the average shown in the table. Due to the use of $\mathrm{Zr}$ crucibles and $\mathrm{NaOH} / \mathrm{Na}_{2} \mathrm{O}_{2}$ in the alkali fusions, $\mathrm{Zr}$ and $\mathrm{Na}$ values, as well as other alkali metals, were determined from the aqua regia digestion. In the case of $\mathrm{B}, \mathrm{Be}, \mathrm{Sb}, \mathrm{Sn}$, and $\mathrm{V}$, both preparations yielded values below the detection limits; hence the lowest detection limit value was selected. Alkali fusion data was used to report values for $\mathrm{Al}$ and Si for the Tank 40 - WAPS sample since the aqua regia preparation fails to dissolve all forms of these elements. The aqua regia data was used to report Cr since the ARG- 1 glass value for Cr by alkali fusion was biased high. For Zn, both the ARG-1 values by alkali fusion and aqua regia were biased high, so the alkali fusion value was used since it was the smaller of the two measured sample values. A similar bias was seen in the alkali fusion $\mathrm{Sr}$ data, but the actual sample results by alkali fusion were slightly lower than those found via aqua regia, so all eight measurements were averaged. ICP-MS analysis of the aqua regia digestion was also used to determine the concentrations of $\mathrm{Cd}, \mathrm{Ce}, \mathrm{Gd}, \mathrm{La}, \mathrm{Nd}, \mathrm{Pb}$, Th, and $\mathrm{U}$. The various isotopes used from the ICP-MS analysis are indicated in the footnotes to Table 3-5. In the case of $\mathrm{Ce}$ and $\mathrm{Nd}$ the distribution of isotopes was not according to their natural abundances but rather the result of fission product yields from U-235. Hence the sum of the 
respective isotopic masses was used to determine the reported concentrations for $\mathrm{Ce}, \mathrm{Nd}$, and $\mathrm{U}$. The $\mathrm{U}$ value reported here from ICP-MS compares to a value determined by ICP-AES of $5.08 \mathrm{wt} \%$ of total solids. For Cd, Gd, and $\mathrm{Pb}$, the reported value was determined from all measured values calculated using the various isotopes' natural abundance. In the case of La-139 and Th-232, a single isotope has essentially $100 \%$ natural abundance and was used to calculate the values given in the table.

Where there are also ICP-AES results for elements reported in Table 3-5 based on their ICP-MS data, these have been included in Table A-1 in Appendix A. There is good agreement between the ICP-MS and ICP-AES results. SRNL is still developing a protocol to propagate the uncertainties for merging the data from the two instruments into a single value for future reports.

Table 3-5. Elemental Concentrations* in Tank 40 SB7b WAPS Samples in Wt. \% of Total Dried Solids (\%RSD**) [Number of Samples Included in Average]

\begin{tabular}{|c|c|c|c|}
\hline Element & Tank 40 - WAPS & Element & Tank 40 - WAPS \\
\hline $\mathrm{Al}$ & $9.18(0.4)[4]$ & Mn & $3.09(0.6)[8]$ \\
\hline $\mathrm{As}^{\wedge \wedge}$ & $<0.0011$ & Mo & 0.00547 (10) [2] \\
\hline B & $<0.016$ & $\mathrm{Na}$ & $14.4(0.7)[4]$ \\
\hline $\mathrm{Ba}$ & $0.0979(1.1)[8]$ & $\mathrm{Ni}$ & $2.69(0.6)[8]$ \\
\hline $\mathrm{Be}$ & $<0.00063$ & $\mathrm{Nd}^{\ddagger \ddagger}$ & $0.251(0.6)[4]$ \\
\hline $\mathrm{Ca}$ & $0.699(0.6)[4]$ & $\mathrm{P}$ & $0.115(1.1)[4]$ \\
\hline $\mathrm{Cd}^{\ddagger}$ & $0.0288(4.0)[4]$ & $\mathrm{Pb}^{\ddagger}$ & $0.0261(5.7)[4]$ \\
\hline $\mathrm{Ce}^{\text {㧊 }}$ & $0.135(0.3)[4]$ & $\mathrm{S}$ & $0.490(1.7)[4]$ \\
\hline Co & 0.0135 (5.5) [8] & $\mathrm{Se}^{\wedge \wedge}$ & $<0.0022$ \\
\hline $\mathrm{Cr}$ & $0.0405(1.0)[4]$ & $\mathrm{Sb}$ & $<0.084$ \\
\hline $\mathrm{Cu}$ & $0.0437(4.0)[8]$ & $\mathrm{Si}$ & $1.11(0.4)[4]$ \\
\hline $\mathrm{Fe}$ & $13.9(0.5)[8]$ & Sn & $<0.044$ \\
\hline $\mathrm{Gd}^{\ddagger}$ & $0.0736(1.5)[4]$ & $\mathrm{Sr}$ & $0.0443(1.9)[8]$ \\
\hline $\operatorname{Hg} \wedge$ & $1.71(3.9)[4]$ & $\mathrm{Th}^{\ddagger}$ & $1.08(5.8)[4]$ \\
\hline $\mathrm{I}-127$ & $0.00105(3.8)[4]$ & $\mathrm{Ti}$ & $0.0181(6.9)[8]$ \\
\hline $\mathrm{K}$ & $0.0536(9.1)[4]$ & $\mathrm{U}^{\ddagger \ddagger}$ & $4.78(1.9)[4]$ \\
\hline $\mathrm{La}^{\ddagger}$ & $0.0730(1.1)[4]$ & V & $<0.00037$ \\
\hline $\mathrm{Li}$ & $0.0247(2.1)[8]$ & $\mathrm{Zn}$ & $0.0396(5.0)[4]$ \\
\hline $\mathrm{Mg}$ & 0.296 (1.8) [8] & $\mathrm{Zr}$ & $0.176(10)[4]$ \\
\hline
\end{tabular}

* ICP-AES data unless specified otherwise

** Parenthetical \%RSD values are relative to the true calculated averages of the quantities in the table, while the average values reported have been rounded off to a reasonable number of significant figures. ¥ Calculated from MS data for Cd: Cd-111, Cd-112, Cd-114; I-127; La-139; Gd: Gd-155, Gd-156, Gd-157, Gd-158, Gd-160; Pb: Pb-206, Pb-207, Pb-208; and Th-232, respectively

\# Calculated from the sum of MS data for Ce: Ce-140 and Ce-142; Nd: Nd-143, Nd-144, Nd-145, Nd-146, Nd-148, and Nd-150; U: U-233, U-234, U-235, U-236 and U-238

$\wedge$ Calculated from CV-AA data

$\wedge$ Calculated from AA data 
A comparison of the major elemental ratios of the insoluble solids using data from Table 3-5 is given in Table 3-6. SRAT Receipt Batch \#614 data is from DWPF and was used to calculate the ratios of Fe to $\mathrm{Al}, \mathrm{Ca}, \mathrm{Mn}$, and $\mathrm{U}$. These ratios should remain constant through batch processing unless an addition of material containing one or more elements of interest is made.

Generally, the elemental ratios observed for SB4 and SB5 are very similar for these major elements. SB6 was the most unique of the last five sludge batches. SB7 ${ }^{13}$ and SB7b are similar in the Ca and U ratios to $\mathrm{Fe}$, but dissimilar in the ratios of $\mathrm{Al}$ and $\mathrm{Mn}$. The agreement between the SB7b WAPS sample and the DWPF Batch \#614 data is generally excellent. The $\mathrm{Al} / \mathrm{Fe}, \mathrm{Mn} / \mathrm{Fe}$ and $\mathrm{U} / \mathrm{Fe}$ ratios are in reasonable agreement with the DWPF data. The lower Ca/Fe ratio for DWPF is probably due mostly to the higher uncertainty in the measurement of this lower abundance metal ion.

Table 3-6. Comparison of Elemental Ratios for Major Insoluble Elements in the Tank 40 SB4, SB5, SB6, SB7a and SB7b Samples with DWPF Batch 614 SRAT Receipt Data

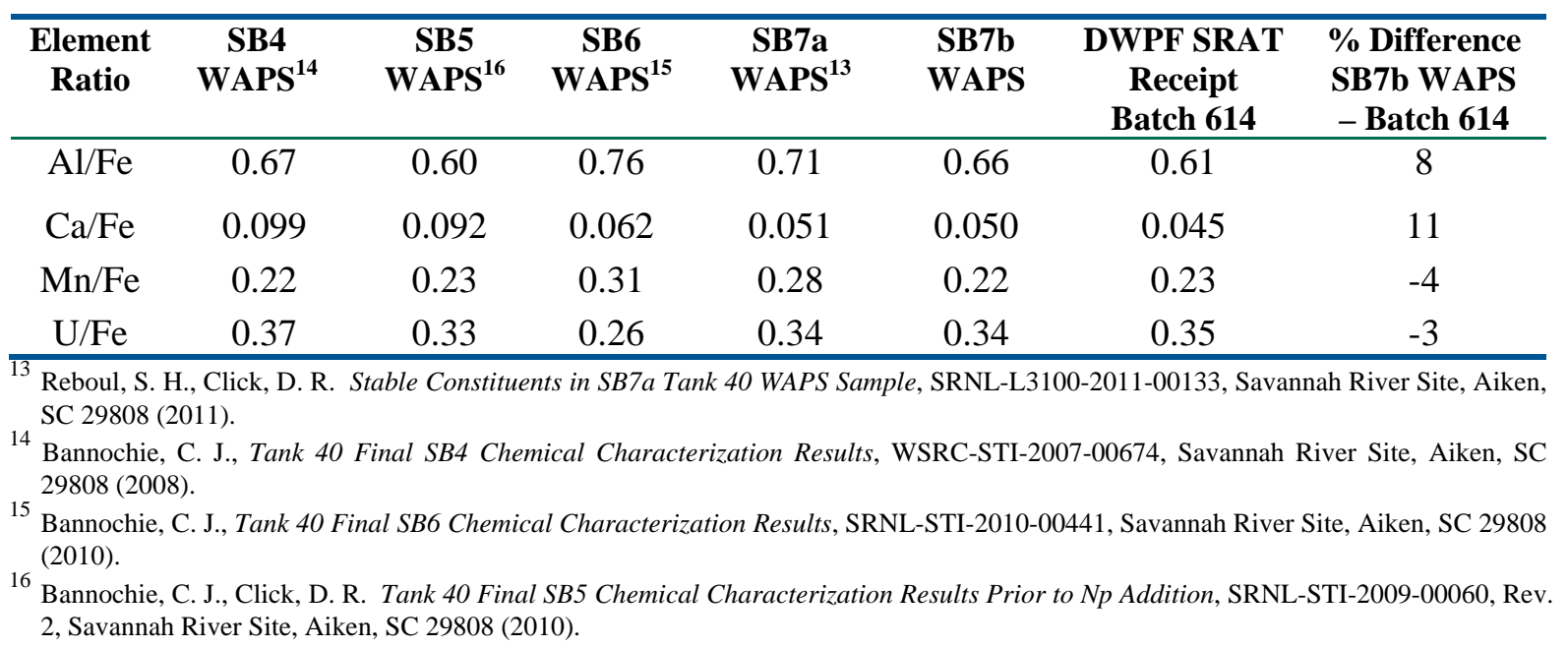

Table 3-7 and Table 3-8 provide the replicate measurements for Fe (whose average was reported in Table 3-5) and the fissile isotopes, U-233, U-235, Pu-239, and Pu-241 for the SB7b WAPS sample, respectively. This data along with the replicate solids and density measurements given in Table 3-9 are reported to allow for the verification of canister fissile limits in DWPF.

Table 3-7. Replicate Concentrations of Iron for the Tank 40 SB7b WAPS Sample in Wt.\% of Total Dried Solids

\begin{tabular}{cccccccc}
\hline Element & Repl. 1 & Repl. 2 & Repl. 3 & Repl. 4 & Average & Instrument & $\begin{array}{c}\text { Prep } \\
\text { Method }\end{array}$ \\
\hline $\mathrm{Fe}$ & 13.8 & 13.9 & 14.0 & 13.9 & 13.9 & ICP-AES & AR \\
$\mathrm{Fe}$ & 13.9 & 14.0 & 14.0 & 14.0 & 14.0 & ICP-AES & PF \\
$\mathrm{Fe}$ & - & - & - & - & 13.9 & ICP-AES & AR/PF \\
\hline
\end{tabular}

$\mathrm{AR} \equiv$ aqua regia digestion, $\mathrm{PF} \equiv$ peroxide fusion digestion 
Table 3-8. Replicate Activities of Fissile Radionuclides for the Tank 40 SB7b WAPS Sample in $\mu$ Ci/g of Total Dried Solids*

\begin{tabular}{ccccccc}
\hline Radionuclide & Repl. 1 & Repl. 2 & Repl. 3 & Repl. 4 & Reported & \%RSD** \\
\hline U-233 & $4.00 \mathrm{E}-02$ & $3.19 \mathrm{E}-02$ & $4.28 \mathrm{E}-02$ & $5.41 \mathrm{E}-02$ & $4.22 \mathrm{E}-02$ & 22 \\
$\mathrm{U}-235$ & $5.73 \mathrm{E}-04$ & $6.18 \mathrm{E}-04$ & $6.31 \mathrm{E}-04$ & $6.24 \mathrm{E}-04$ & $6.12 \mathrm{E}-04$ & 4.3 \\
$\mathrm{Pu}-239$ & $1.06 \mathrm{E}+01$ & $1.07 \mathrm{E}+01$ & $1.10 \mathrm{E}+01$ & $1.07 \mathrm{E}+01$ & $1.08 \mathrm{E}+01$ & 1.4 \\
Pu-241 & $<3.0 \mathrm{E}+01$ & $<1.5 \mathrm{E}+02$ & $<1.8 \mathrm{E}+01$ & $5.09 \mathrm{E}+01$ & $5.09 \mathrm{E}+01$ & NA \\
\hline
\end{tabular}

NA $\equiv$ not applicable

* ICP-MS data unless specified otherwise

${ }^{\ddagger} \mathrm{Pu}-238 /-241$ method. See Ref. 8 for description.

**Values in the \%RSD column are relative to the true calculated averages of the quantities in the table, while the average values reported have been rounded off to a reasonable number of significant figures.

Unlike SB6 ${ }^{15}$ which was enriched to 0.756 wt.\% U-235, both SB7a (0.658 wt.\% enrichment) and SB7b (0.592 wt.\% enrichment) are not enriched in U-235. Normal U enrichment is 0.711 wt.\%.

Table 3-9. Replicate Weight Percent Solids and Densities for Tank 40 SB7b WAPS Sample

\begin{tabular}{|c|c|c|c|c|c|c|}
\hline $\begin{array}{c}\text { Species } \\
\text { (Wt.\% Solids are } \\
\text { Slurry Basis) } \\
\end{array}$ & $\begin{array}{c}\text { Replicate } \\
1\end{array}$ & $\begin{array}{c}\text { Replicate } \\
2\end{array}$ & $\begin{array}{c}\text { Replicate } \\
3\end{array}$ & $\begin{array}{c}\text { Replicate } \\
4\end{array}$ & $\begin{array}{c}\text { Replicate } \\
5\end{array}$ & Average \\
\hline Wt.\% Total Solids & 15.64 & 15.60 & 15.65 & 15.66 & NA & 15.64 \\
\hline Wt.\% Calcined Solids & 12.32 & 12.52 & 12.99 & 12.18 & NA & 12.50 \\
\hline Slurry Density, g/mL & 1.109 & 1.120 & 1.125 & 1.120 & NA & 1.12 \\
\hline Supernate Density, g/mL & 1.052 & 1.052 & 1.047 & 1.049 & 1.043 & 1.05 \\
\hline
\end{tabular}

NA $\equiv$ not applicable

Table 3-10 provides Tank Farm requested data on the amount of Cs-137 in the Tank 40 supernate needed for corrosion control activities.

Table 3-10. Cesium-137 Concentration in the Tank 40 SB7b WAPS Sample Supernate in $\mathbf{d p m} / \mathrm{g}\left(\% \mathrm{RSD}^{* *}\right)$ [Number of Samples Included in Average]

\begin{tabular}{|c|c|}
\hline Isotope & Average \\
\hline Cs-137 & $9.04 \mathrm{E}+07$ (1.5) [4] \\
\hline
\end{tabular}

The fission product noble metal and silver concentrations are given in Table 3-11 and Figure 3-1. The values were calculated from ICP-MS data using an Excel spreadsheet. This spreadsheet uses the fission yield for each isotope to account for the mass contribution from isotopes in the tank that could not be measured because isotopes of natural Cd interfere at this mass. An example of this is the measurement at mass 110, which is comprised of Pd-110 and Cd-110. The uncertainties were analyzed using statistical techniques appropriate for replicate measurements of non-highly correlated data. For 
comparison purposes, the SB4 WAPS ${ }^{14}$, SB5 WAPS ${ }^{16}$, SB6 WAPS ${ }^{15}$ and SB7a WAPS samples are also given in this table. The results indicate there has been a general leveling off in fission product noble metal and silver concentrations over the past five sludge batches. The silver concentration appears to have peaked in SB7a, [Pd] peaked in SB6, and [Ru] peaked in SB7b, while [Rh] has been fairly constant across SB6, SB7a, and SB7b.

Table 3-11. Noble Metal Fission Product and Silver Concentrations in Tank 40 SB4, SB5, SB6, SB7a, and SB7b WAPS Samples in Wt. \% of Total Solids (\%RSD)

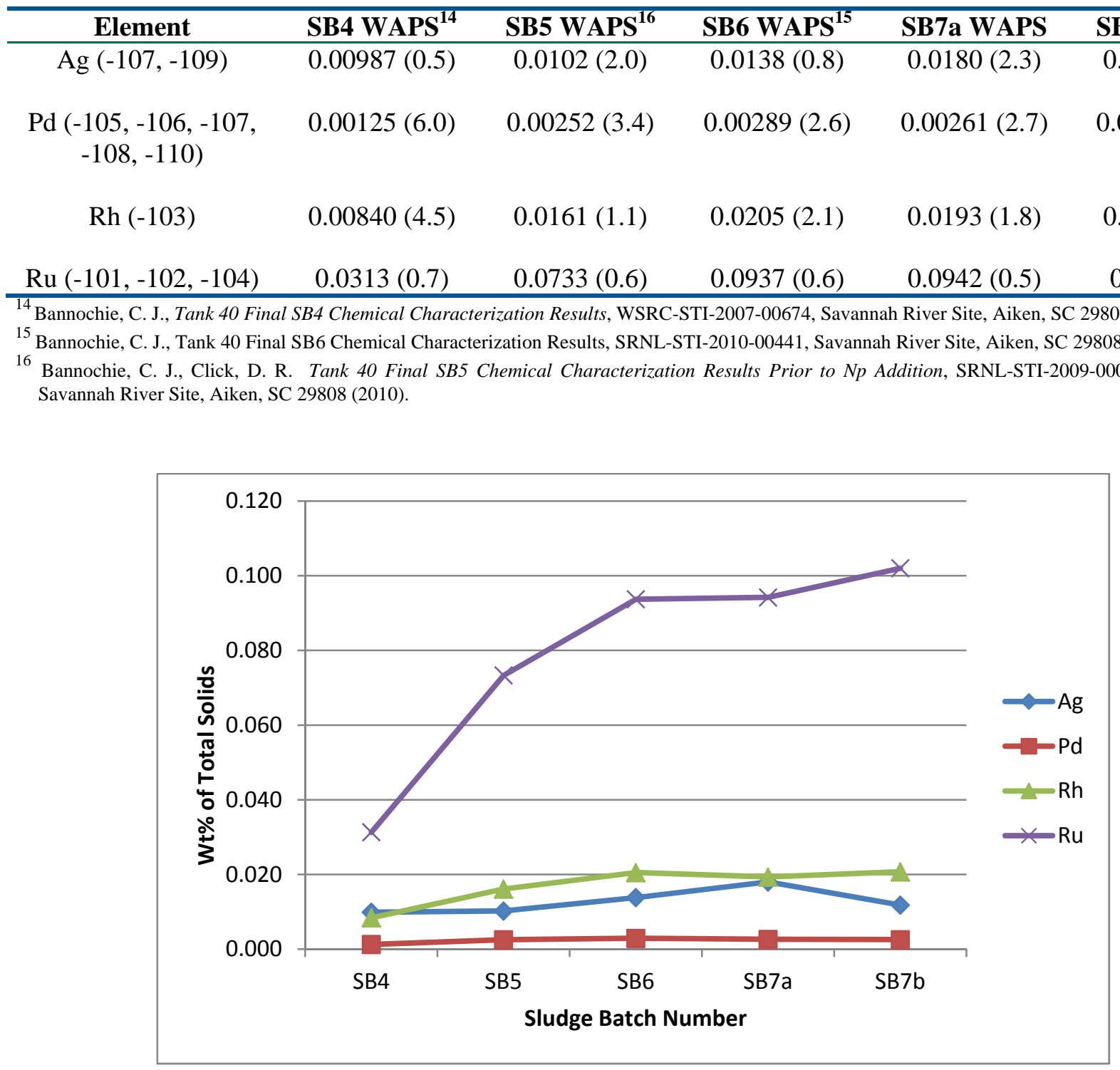

Figure 3-1. Noble Metal Fission Product and Silver Concentrations (Wt. \% of Total Solids) in Tank 40 WAPS Samples for SB4 through SB7b

A comparison of the fission yield mass ratios for $\mathrm{Ru}: \mathrm{Rh}, \mathrm{Ru}: \mathrm{Pd}$, and $\mathrm{Ru}$ :Ag with those measured for the SB7b WAPS sample is provided in Table 3-12. The SB4, SB5, SB6, and SB7a WAPS sample results are also provided for comparison. The mass ratios are based upon $\mathrm{Ru}$ due to its relatively high 
concentration in the sludge as compared with the other noble metals. The Ru:Rh ratio agrees reasonably well but does appear to be trending up across all five samples, while the Ru:Ag ratios differ significantly from the fission yield ratios. This lack of agreement for the Ag ratios is not unexpected. The majority of the Ag is natural Ag originating from Ag saddles used in the dissolvers to scavenge radioactive iodine, while the noble metals are fission products of $\mathrm{U}-235$. Consequently the relative concentration of Ag is not expected to be in proportion to the fission yields of its two isotopes. The Ru:Pd ratios agree reasonably well amongst the three samples but not with that predicted by the fission yield. A possible explanation for this is that a portion of the Pd is soluble and hence has fractioned off into the salt waste, thus increasing the ratio of $\mathrm{Ru}$ to $\mathrm{Pd}$ in the sludge waste. This fractionation appears to be increasing over the last five sludge batches.

Table 3-12. Fission Yield Ratios and Measured Noble Metal Ratios in SB4, SB5, SB6, SB7a, and SB7b WAPS Samples

\begin{tabular}{lcccccc}
\hline Ratio & $\begin{array}{c}\text { Fission } \\
\text { Yield }\end{array}$ & SB4 WAPS $^{\mathbf{1 4}}$ & SB5 WAPS $^{\mathbf{1 6}}$ & SB6 WAPS $^{15}$ & SB7a WAPS $^{\text {SB7b WAPS }}$ \\
\hline Ru:Rh & 3.7 & 3.7 & 4.6 & 4.6 & 4.9 & 4.9 \\
Ru:Pd & 6.9 & 25 & 29 & 32 & 36 & 40 \\
Ru:Ag & 342 & 3.2 & 7.2 & 6.8 & 5.2 & 8.6 \\
\hline${ }^{14}$ Bannochie, C. J., Tank 40 Final SB4 Chemical Characterization Results, WSRC-STI-2007-00674, Savannah River Site, Aiken, SC 29808 (2008). \\
${ }^{15}$ Bannochie, C. J., Tank 40 Final SB6 Chemical Characterization Results, SRNL-STI-2010-00441, Savannah River Site, Aiken, SC 29808 (2010). \\
${ }^{16}$ Bannochie, C. J., Click, D. R. Tank 40 Final SB5 Chemical Characterization Results Prior to Np Addition, SRNL-STI-2009-00060, Rev. 2, \\
Savannah River Site, Aiken, SC 29808 (2010).
\end{tabular}

\subsection{Conclusions}

- The ratios of the major elements for the SB7b WAPS sample are different from those measured for the SB7a WAPS sample. There is less $\mathrm{Al}$ and $\mathrm{Mn}$ relative to $\mathrm{Fe}$ than the previous sludge batch.

- The elemental composition of this sample and the analyses conducted here are reasonable and consistent with DWPF batch data measurements in light of DWPF pre-sample concentration and SRAT product heel contributions to the DWPF SRAT receipt analyses. The element ratios for $\mathrm{Al} / \mathrm{Fe}, \mathrm{Ca} / \mathrm{Fe}, \mathrm{Mn} / \mathrm{Fe}$, and $\mathrm{U} / \mathrm{Fe}$ agree within $10 \%$ between this work and the DWPF SRAT receipt analyses.

- Sulfur in the SB7b WAPS sample is $82 \%$ soluble, slightly less than results reported for SB3, SB4, and SB6 samples but unlike the 50\% insoluble sulfur observed in the SB5 WAPS sample. In addition, $23 \%$ of the soluble sulfur is not present as sulfate in SB7b.

- The average activities of the fissile isotopes of interest in the SB7b WAPS sample are (in $\mu \mathrm{Ci} / \mathrm{g}$ of total dried solids): 4.22E-02 U-233, 6.12E-04 U-235, 1.08E+01 Pu-239, and 5.09E+01 Pu241. The full radionuclide composition will be reported in a future document.

- The fission product noble metal and Ag concentrations appear to have largely peaked in previous DWPF sludge batches, with the exception of Ru, which still shows a slight increase in SB7b. 


\subsection{References}

1. Office of Environmental Restoration and Waste Management, Waste Acceptance Product Specifications for Vitrified High-Level Waste Forms, US DOE Document DOE/EM-0093, Rev. 2, (12/96).

2. Bricker, J. M. Sludge Batch 7b Qualification Studies, HLW-DWPF-TTR-2011-0004, Rev. 0, Savannah River Site, Aiken, SC 29808 (2010).

3. Pareizs, J. M., Click, D. R. Task Technical and Quality Assurance Plan for Sludge Batch 7B Qualification in the Shielded Cells, SRNL-RP-2011-00247, Rev. 0, Savannah River Site, Aiken, SC 29808 (2011).

4. Pareizs, J. M., Click, D. R. Analytical Study Plan for Qualification of Sludge Batch $7 b$ in the Shielded Cells:, WSRC-RP-2009-00474, Rev. 1, Savannah River Site, Aiken, SC 29808 (2009).

5. Coleman, C. J. Aqua Regia Dissolution of Sludge for Elemental Analysis, Manual L16.1, Procedure ADS-2226, Rev. 9, Savannah River Site, Aiken, SC 29808 (2009).

6. Coleman, C. J. Alkali Fusion Dissolutions of Sludge and Glass for Elemental and Anion Analysis, Manual L16.1, ADS-2502, Rev. 6, Savannah River Site, Aiken, SC 29808 (2008).

7. Smith, G. L. Characterization of Analytical Reference Glass - 1 (ARG-1), PNL-8992, Pacific Northwest (National) Laboratory, Richland, WA (1993).

8. Bannochie, C. J., DiPrete, D. P. Determination of Reportable Radionuclides for DWPF Sludge Batch 6 (Macrobatch 7), SRNL-STI-2011-000189, Savannah River Site, Aiken, SC 29808 (2011).

9. Marek, J. C. Correction Factor for Soluble and Insoluble Solids, SRTC-PTD-92-0040, Savannah River Site, Aiken, SC 29808 (1992).

10. Pareizs, J. M., Weight Percent Solids Determination Using A Furnace or Oven, Manual L29, Procedure ITS-0078, Rev. 0, Savannah River Site, Aiken, SC 29808 (2007).

11. Bannochie, C. J., Click, D. R., and Pareizs, J. M. Sludge Batch 7 Preparation: Tank 4 and 12 Characterization, SRNL-STI-2010-00223, Savannah River Site, Aiken, SC 29808 (2010).

12. Bannochie, C. J., Fellinger, T. L, and Pareizs, J. M. Tank 40 Final SB3 Chemical Characterization Results, WSRC-TR-2005-00049, Savannah River Site, Aiken, SC 29808 (2005).

13. Reboul, S. H., Click, D. R. Stable Constituents in SB7a Tank 40 WAPS Sample, SRNL-L3100-201100133, Savannah River Site, Aiken, SC 29808 (2011).

14. Bannochie, C. J., Tank 40 Final SB4 Chemical Characterization Results, WSRC-STI-2007-00674, Savannah River Site, Aiken, SC 29808 (2008).

15. Bannochie, C. J., Tank 40 Final SB6 Chemical Characterization Results, SRNL-STI-2010-00441, Savannah River Site, Aiken, SC 29808 (2010). 
16. Bannochie, C. J., Click, D. R. Tank 40 Final SB5 Chemical Characterization Results Prior to Np Addition, SRNL-STI-2009-00060, Rev. 2, Savannah River Site, Aiken, SC 29808 (2010). 


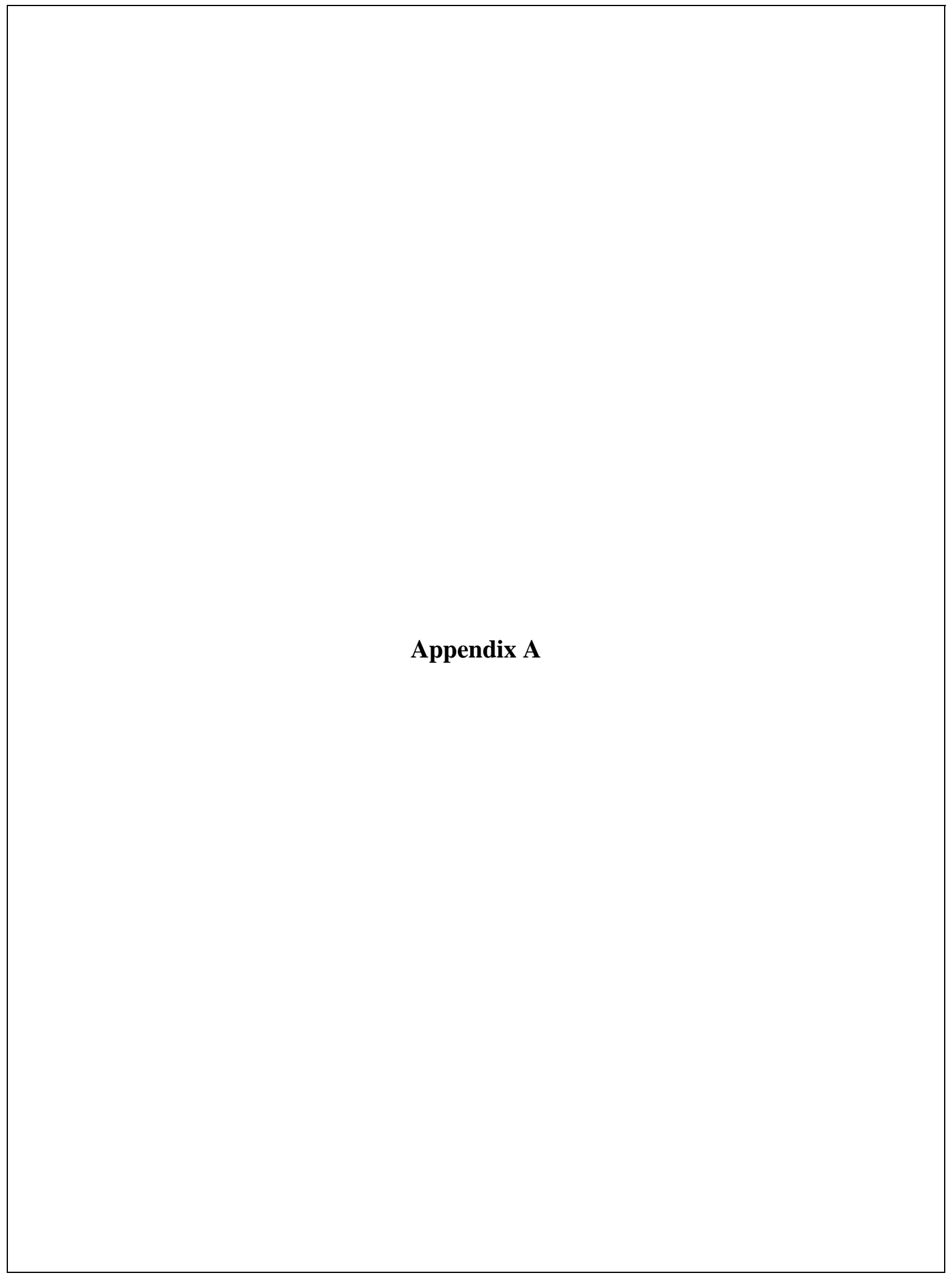


Table A-1. ICP-AES Results for Elements Reported Based on ICPMS Data in Table 3-5 for Tank 40 SB7b WAPS Samples in Wt.\% of Total Dried Solids (\%RSD**) [Number of Samples Included in Average]

\begin{tabular}{cc}
\hline Element & Tank 40 - WAPS \\
\hline $\mathrm{Cd}$ & $0.0309(4.1)[8]$ \\
$\mathrm{Ce}$ & $0.138(12)[8]$ \\
$\mathrm{Gd}$ & $0.0698(23)[8]$ \\
$\mathrm{La}$ & $0.0628(5.9)[8]$ \\
$\mathrm{Pb}$ & $0.0313(1.1)[4]$ \\
$\mathrm{Th}$ & $1.08(5.0)[8]$ \\
$\mathrm{U}$ & $5.08(0.8)[8]$ \\
\hline ** Parenthetical \%RSD values are relative to the true calculated averages of the \\
quantities in the table, while the average values reported have been rounded off to a \\
reasonable number of significant figures.
\end{tabular}




\section{Distribution:}

S. L. Marra, 773-A

A. B. Barnes, 999-W

S. D. Fink, 773-A

B. J. Giddings, 786-5A

C. C. Herman, 999-W

F. M. Pennebaker, 773-42A

J. P. Vaughan, 773-41A

C. M. Jantzen, 773-A

C. L. Crawford, 773-42A

J. M. Pareizs, 773-A

S. H. Reboul, 773-A

T. B. Edwards, 999-W

K. M. Fox, 999-W

F. C. Johnson, 999-W

D. C. Koopman, 999-W

D. P. Lambert, 999-W

J. D. Newell, 999-W

D. K. Peeler, 999-W

M. E Stone, 999-W

J. R. Zamecnik, 999-W

J. W. Amoroso, 999-W

P. R. Jackson, 703-46A

J. M. Bricker, 704-27S

A. Samadi-Dezfouli, 704-27S

M. A. Broome, 704-29S

T. L. Fellinger, 704-26S

R. N. Hinds, 704-S

E. W. Holtzscheiter, 704-15S

J. F. Iaukea, 704-30S

R. T. McNew, 704-27S

E. J. Freed, 704-S

J. W. Ray, 704-S

D. C. Sherburne, 704-S

H. H. Elder, 704-24S

J. M. Gillam, 766-H

D. A. McIlmoyle, 766-H

M. T. Keefer, 766-H

H. B. Shah, 766-H

M. A. Rios-Armstrong, 241-156H

A. R. Shafer, 241-197H

K. H. Subramanian, 249-8H

A. W. Wiggins, 705-1C 